\title{
Representation of agricultural producers' interests: substantiation of the research construct
}

\author{
Agota Giedrè Raišienè, Artiom Volkov, \\ Virgilijus Skulskis, Rita Vilkè \\ Lithuanian Institute of Agrarian Economics, Lithuania
}

\section{Keywords:}

Agriculture

Farmers

Participatory

Governance

Article history:

Received

19.06.2018

Received in

revised form

20.08.2018

Accepted

28.09.2018

Corresponding author:

Agota Giedrè

Raišienè

E-mail:

agotagiedre@

gmail.com
DOI:

$10.24263 / 2304-$

974X-2018-7-3-16

\section{Abstract}

Introduction. The research aims to substantiate a construct of the scientific research which enables assess the associated agricultural producers' involvement in agricultural policy-making processes.

Materials and methods. Methods of scientific discourse analysis, survey of agricultural producers, statistical data analysis, systematization and synthesis of scientific insights were used. The theoretical background is based on analysis of management theories explaining a nature of inter-organizational interaction.

Results and discussion. Representation of agricultural producers' interests in policy making processes is inappropriate. We chose Lithuania as example and found that even 85.6 percent of farmers are completely not members of any association or union and only about 10 percent of them participate in activities of organizations of agricultural area. The research results show that in the context of EU financial support for agriculture the problem of stakeholder participation in policy making processes deforms the opportunities of big and small farmers to defend their interests. Participative and Collaborative Governance and concept of partnership and inter-organizational collaboration were achieved i) by distinguishing characteristic groups of associated agricultural producer organizations' participation in agricultural policy making processes, ii) by compiling a scheme of research on the balance of need satisfaction and interest expression of associated agricultural producers, and iii) by forming theory-based battery of interview questions for further qualitative survey was. During analyzing results of research it was found that the implementation of interests based on needs should become a core task for policy makers. In order to do so, it must be ensured that stakeholders' influential power is balanced, and the needs of all interest groups are appropriately evaluated. The research results show that the assumptions for better opportunities to take agricultural stakeholder needs into consideration when forming and implementing agricultural policy could be strengthened.

Conclusions. Research allows systematically gather qualitative data and better substantiates recommendations to politicians and representatives of agricultural producer associations. 


\section{Economics and Management -}

\section{Introduction}

A competitive advantage of organization mostly is influenced by management decisions whereas in agricultural sector the competitiveness is distorted due to the EU support opportunities which essentially are only distributed taking the size of a given farm into consideration $[7 ; 40 ; 41 ; 37]$. Due to this reason, the business and operating conditions of larger-scale farmers are improved quicker than those of smaller ones. Financial support for larger-scale farms allows them to expand, purchase more or more advanced agricultural machinery, implement technological innovations etc. [25; 22; 19].

Furthermore, the differences in farming conditions are influenced by insufficiently justified agricultural policy priorities on a national level in most of post-Soviet countries, and Baltic countries are among them [6;25;37]. The support system in agriculture is formed to support farmers using the same principle without considering their needs, activity opportunities and objective constraints. On the other hand, even though farmers unite into associations and other organized entities, the interests of some of them in the context of agricultural policy are not being protected sufficiently [26].

With the start of a new EU financial period coming near in 2020, the abovementioned issues become especially significant. In addition to that, scientific research on administration effectiveness, business competitiveness and balanced representation of stakeholder interests in making decisions remain important as well $[29 ; 22 ; 7]$. Considering relevance, the aim of the article was defined: on the bases of scientific literature and results of the survey to substantiate a research construct which would enable to assess the associated agricultural producers' involvement in agricultural policy-making processes.

The research developed in later stages would allow the agricultural producers to better protect their interests in pursuing competitiveness in agricultural business and farming. It would also enable the political decision-makers to better understand the nature of stakeholders' needs and differences between them.

\section{Materials and methods}

With the aim to substantiate a research construct which would enable to assess the associated agricultural producers' involvement in agricultural policy-making processes, methods of i) scientific discourse analysis, ii) survey of farmers, iii) statistical analysis of primary data, iv) statistical analysis of secondary data, and v) systematization and synthesis of insights were used. The theoretical background of the article is based on management theories explaining a nature of inter-organizational interaction, and that are: Transaction Costs Economics theory [18; 27; 39], Stakeholders theory [11; 21; 28] and Network theory $[2 ; 3 ; 23 ; 32]$, whereas principles of interest representation and stakeholders' participation in policy making and implementation processes are explained by the concepts of participatory and collaborative governance $[9 ; 20 ; 29]$, also social partnership and interorganizational collaboration ideas $[31 ; 34 ; 17]$ were taken into consideration. Common agricultural policy (CAP) effect on farm development was based on statistical data of Eurostat, and survey of agricultural producers in Lithuania as one of examplar was completed with the aim to reveal context and relevance of the research construct. 


\section{Results and discussion}

\section{Research context: Common agricultural policy effect on farm development in Lithuanian}

The peculiarities of agriculture in Lithuania reduce the agricultural sector's resistance to negative factors both inside and outside the country and sector. These peculiarities were influenced by various conditions, the most significant of which are the implementation of Common Agricultural Policy (CAP) based on the EU support, specifics of national priorities in agriculture and lack of unity between agricultural producers in defending their essential interests.

The criticism on common agricultural policy, especially the imperfectness of direct payment system and its inability to implement the set goals is sore for over a decade [14; $5 ; 40 ; 41 ; 35]$. On one hand, the direct payment system is criticized by the society for spending public funds and constantly facing environmental and animal well-being problems. On the other hand, farmers are dissatisfied with the increasing inequality of income and, in their opinion, unjust distribution of direct payment system elements [22].

Back in 2005-2010, Lithuania was already one of the few EU countries with dominant effect of farm structure polarization, where the number of big farms (over 100 ha) doubled, the number of small farms (under $5 \mathrm{ha}$ ) increased slightly while the number of average farms decreased [25]. This phenomenon indicated an instable agricultural structure, the foundation of which (the average farms) was vulnerable and of low viability.

In 2016, compared to 2005, the number of farms over 100 ha and more in size increased by 114 percent in Lithuania, while in the EU-28 this number was only 11 percent on average (Figure 1). The number of farms of 10 to 100 ha decreased by 32.2 percent in this period while the number increased by 13 percent in the EU. Lastly, the number of farms under 10 ha decreased both in the EU and Lithuania - 33.2 and 44.9 percent decrease respectively. It should be noted that in Lithuania, the number of farms under 10 ha and farms between 10 and 100 ha decreased twice as quickly as in rest of the EU.

According to Lithuanian agricultural structure, in 2016 there were 107.8 thousand farms under 10ha. The number of farms over 100 ha was only 5.3 thousand, however, their owners owned almost 3.5 times more area by hectares. In other words, currently in Lithuania, 3.5 percent of landowners control more than 50 percent of all agricultural land utilities.

The changes in Lithuanian agricultural structure became clear after implementing the direct payment system and applying a one-time payment-for-area scheme [25]. A support system based on payments for owned agricultural land utility area in hectares had a strong influence on the changes in types of production generated in farms. Farmers significantly increased investment into grain growing as an activity that requires big areas of land. This allowed to ensure direct financial returns through direct payments with relatively low work and capital input requirements per 1 ha of land [37]. The consequences of decision to grow more grain are especially visible comparing years 2005 and 2016. In 2016, Lithuania became a leader in the change of grain growing farms amongst all EU member countries. In this time period, the number of grain growing farms in Lithuania increased by 346 percent while the growth in the EU was only 7 percent on average. It should be emphasized that the area of arable land used in farms increased as well - an increase of 186 percent is observed. 

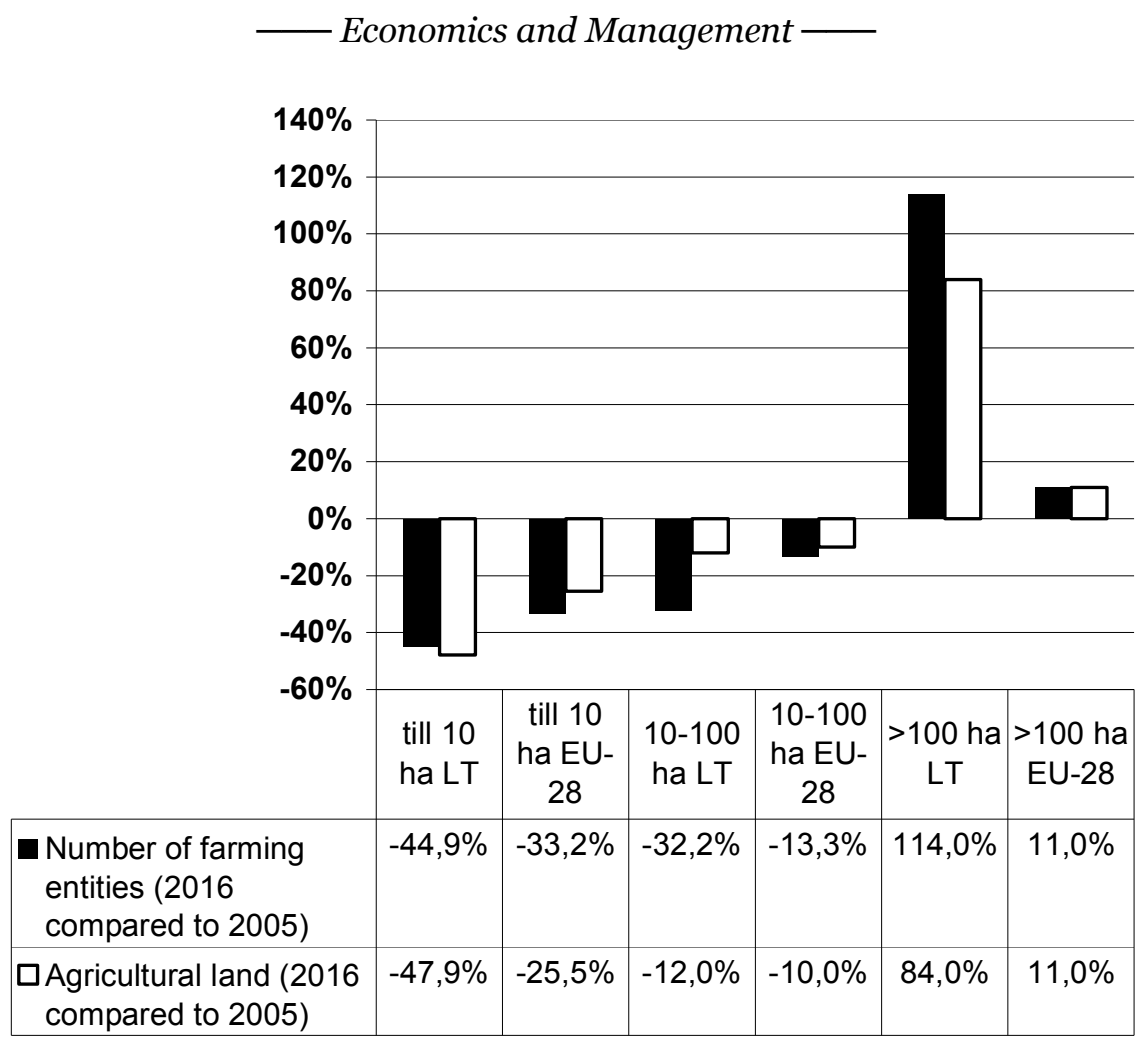

Figure 1. The change in the number of farms and farmland in different groups by size in Lithuania and on average in EU-28, 2016 compared to 2005. Source: authors compilation based on EUROSTAT.

The support measures of common agricultural policy had an influence on Lithuanian agricultural structure changes too. Some national level rules of financial support for agriculture made it easier for larger-scale farms, especially those over 100 ha to receive bigger support. Due to production potential being directly proportional to farm size, big farmers became more attractive to financial credit companies while the owners of small farms were assigned a higher risk group and lost a part of opportunities to acquire or develop their competitive advantage by investing into new activities or development.

Summing it up, the abovementioned reasons and conditions in Lithuania caused: i) agricultural structure changes and decrease in farm numbers; ii) vulnerability of farms growing other production than grain; iii) competitive imbalance between farms considering both size and production type; iv) contraposition of small and big farmers; v) more evident display of social inequality; vi) imbalance of agricultural producers' interest representation in agricultural policy making observed through political decisions that insufficiently satisfy the needs and interests of small farmers. However, in order to objectively evaluate if and how the size of the farm is related to the representation of interests of its owner in agricultural policy making and to provide recommendations which would allow to ensure adequate satisfaction of agricultural producers' needs, a definition of small, average and big farms has to be formed. 


\section{Economics and Management -}

The area of the farm is one of the most commonly used criteria in statistical, economic and political analyses which determine the boundaries between small and other farms. Small farms are defined differently in different countries: fewer than 2 ha, under 5 ha, under 10 ha of land utilities or 10 percent of smallest farms that declare land utilities [6;19; 10]. Thus, if an agreement was made in Lithuania on what criteria would allow to unambiguously classify farms by their size, it would be possible to more clearly evaluate the potency of farmer group interest representation and to pursue a common societal wellbeing by executing a more effective and favorable agricultural policy.

\section{Relevance of agricultural producers' interests representation research}

A survey of agricultural producers was carried out to determine the relevance of scientific research problem. An original representative empirical data were collected by experienced research subcontractor. Population of Lithuanian farmers equals to $\mathrm{N}=138.9$ thousand. Calculated representative population under statistical conditions of 3 percent error $(\varepsilon=0.05)$ and 95 percent $(p=0.5)$ confidence level is $n=1059$. Respondents were selected using systemic sampling of research subcontractors' database. Data were collected using telephone interviews of Lithuanian farmers in January-February 2017. Potential respondents had been telephoned 3211 times, 1491 times without response, 612 farmers rejected the suggestion to take part in the interview. Finally, 1108 interviews were found suitable for further investigations which satisfy defined statistical conditions.

The obtained data was processed with descriptive statistical analysis. The percentage distribution of respondents' answers was calculated, comparing data between the groups by using $\chi^{2}$ test (significance level $p<0.05$ ). The sample size of the study allows ensuring that the statistical error of the results does not exceed 3.1 percent. Statistical analysis of data was performed using the SPSS 20.0 program. A two-stage variable $\chi^{2}$ independence test was performed to determine whether the respondent's characteristics (sex, age, etc.) affect the distribution of answers to questions. Only those answers are used as evidence, in which the test showed that the distribution of answers depends on the respondents' characteristics.

The study involved 57.7 percent men and 42.3 percent women. The majority of surveyed farmers ( 38.3 percent) were respondents aged from 55 to 64 ; the second age group (27.6 percent) was farmers aged between 45 and 54, respondents of 65 years and older composed 23.9 percent. The smallest group of respondents is represented by youngest farmers: 1.1 percent is up to 35 years and 9.1 percent aged between 35 and 44 . The majority of respondents ( 34.5 percent) had acquired professional education; farmers with acquired upper and secondary education composed respectively 23.7 percent and 21.4 percent. The smallest group of respondents according to their education consists of respondents with lower secondary ( 4.6 percent) and primary education (1.6 percent). The majority ( 88.4 percent) of the surveyed farmers acquired education before 1990 (or in the Soviet period), 10 percent - before the Lithuania's accession to the EU (i.e. in the period of 1990-2004) and 1.6 percent in 2005 or later, i.e. after Lithuania's accession to the EU.

The majority of respondents ( 44.8 percent) are farmers whose farm size is up to 20 hectares (ha); 32.1 percent - from 20.1 to 50 ha; 13.7 percent - from 50.1 to 100 ha. The smallest part of the respondents are farmers with farms of 100.1 to 500 ha (9.2 percent) and more than 500.1 ha $(0.2$ percent).

According to the criterion of the duration of the activity, almost half of the surveyed farmers (46.6 percent) started their farming activities 21 year ago or even earlier, a similar proportion of respondents (43.1 percent) - from 11 to 20 years ago, and the youngest farms with experience 10 and less years of farming composed 10.3 percent. More than half of the 
respondents (54.1 percent) have mixed (both crop and livestock) farms, 21.5 percent are crop farmers, and livestock farmers compose 13.3 percent.

By summarizing the general statistical characteristics of the survey, it can be stated that given data is representative.

Talking about research insights, it should be emphasized that representation of agricultural producers' interests in is inappropriate. Even 85.6 percent of farmers are not members of any organization (e.g. association, union, confederation, etc.) and only about 10 percent of farmers participate in activities of organizations of their professional area (Figure 2).

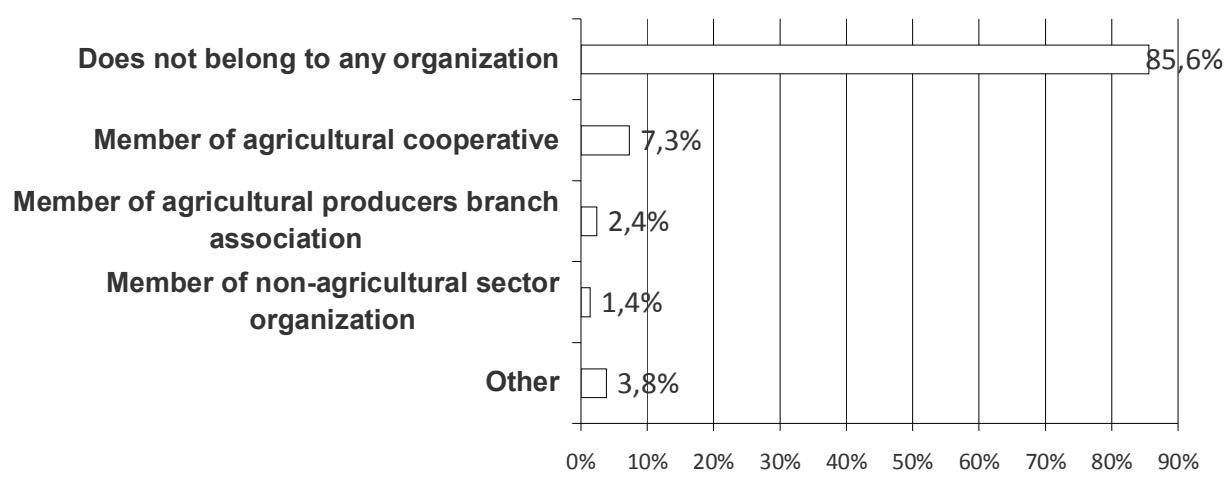

Figure 2. Agricultural producers' participation in organized activities.

Source: authors.

A similar portion of farmers shows personal initiative to cooperate having an aim to protect common interests (Table 1).

On the other hand, 53.8 percent of respondents are ready to contribute in case of joint activity were organized in their community or rural area, or area of their professional expertise (Figure 3).

Table 1

Distribution of answers to the question "Have you ever asked other farmers to cooperate with the aim to protect common interests?"

\begin{tabular}{|l|c|c|}
\hline & Frequency & Percent \\
\hline Yes & 147 & $\mathbf{1 3 , 3}$ \\
\hline No & 958 & $\mathbf{8 6 , 4}$ \\
\hline Other & 3 & 0,3 \\
\hline Total & 1108 & 100 \\
\hline
\end{tabular}

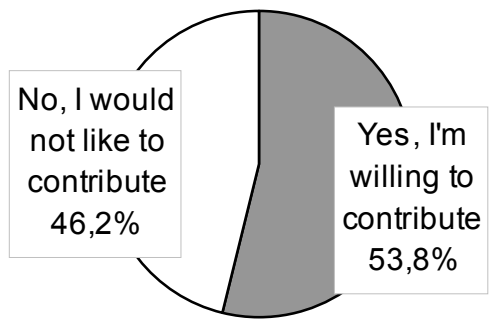

Source: authors.

Figure 3. Farmers' willingness to contribute in joint activity.

Source: authors. 


\section{- Economics and Management -}

The contradiction between attitudes and behavior of farmers can lead to a question of what determines the situation that farmers do not enter organizations for joint activities although they have willingness for this. In order to answer this question, qualitative research construct is modeled and presented further.

\section{Construct of research on representation of associated agricultural producers ${ }^{6}$ interests: theoretical background}

The plan of the research on associated agricultural producers' opportunities to satisfy the needs of represented farmers was based on a theoretical basis which would allow to explain the relationship between the society, country and business and would allow to understand what principles and assumptions should be followed to coordinate the goals of all sides.

Management theory analysis has allowed to distinguish three theories complying with this goal: Transaction Costs Economics theory, Stakeholders theory and Network theory, whereas principles of interest representation and stakeholders' participation in policy making and implementation processes are explained by the concepts of participatory and collaborative governance.

In this context, social partnership and interorganizational collaboration ideas were taken into consideration. They allowed to emphasize the essential goal and principle assumptions of joint actions of all stakeholders.

Transaction Costs Economics theory. Transactions costs economics theory (TCE) is based on specific assumptions. The first assumption states that an individual's behavior is opportunistic, and "self-interest is unconstrained by morality" [27]. The second assumption regards the requirement for success. Here, "efficiency" within predefined rules of the game is the criterion that determines the desirability of the outcome [39]. However, actors will not behave opportunistically by all means. The probability of opportunism occurring increases as asset specificity increases [18]. „Opportunism occurs when outcomes are highly uncertain, reputation is difficult to establish, and the payoff from opportunism in the present period outweighs the discounted present value of future cooperation" [18]. On the other hand, organizations have the ability to reduce opportunism through hierarchical control [15]. Thus, collaborative activities between the transaction parties are of major importance to the economic results the organization achieves. However, positive results are not always achieved. For example, when the number of interacting sides with influential power is low, competition occurs. It is especially relevant in the context of associated agricultural producer organizations and their influence on country-level decisions on agricultural sector. Ensuring that all stakeholders directly related to the decision are able to adequately participate in decision making processes becomes a crucial factor.

Stakeholder Theory. The Stakeholder Theory (SHT) connects the economic and social aspects of an organization and allows explaining the nature of relationships important to the existence of the organization [11]. According to SHT, the interests of all stakeholders are important, thus there should be no dominant interests [21]. An organization which takes into consideration the interests of all stakeholders sooner or later wins the competitive battle against an organization which only considers limited interests or bestows privilege on a particular interest group [8]. On an interorganizational level, SHT allows to solve the problem of organizational relations and interaction. The selection and inclusion of associated stakeholders should depend on the relevant issue and tasks being solved by the 
organization in given circumstances. With this goal in mind, Mitchell et al. offer to determine to what extent the stakeholders are significant in the organization, evaluating three attributes of organizational relations: 1) power to influence the organization, 2) legitimacy of the relationship between organization and the stakeholder and 3) urgency of reacting to stakeholders' demands [28]. Stakeholders that correspond with only one attribute are called latent; those that correspond with two attributes are called expectant while those that correspond with all the attributes are called definitive stakeholders. It is also possible that a group or organization does not correspond with any of the attributes, in which case they are considered potential stakeholders. It should be noted that power, legitimacy and urgency can change depending on circumstances. Due to this reason, attributes may be gained or lost [28]. Thus, the significance of a stakeholder should be evaluated every time taking into consideration both changes and reality. Moreover, stakeholders can be external and internal, part of which can have overlapping interests. This way, different stakeholders may have different opportunities for creating mutual benefit in the stakeholder relationship [30].

Frooman refills SHT by claiming that stakeholders tent to influence organization management and decision making: "The appropriateness of a stakeholder's claim may not matter nearly as much as the ability of the stakeholder to affect the direction of the firm." [12, p. 193]. Therefore, such characteristics of interaction as participation basis and relationship structure should be taken into account for stakeholder analysis and mapping. A proper understanding of stakeholders' interests and power is crucial for efficiency of organization management.

The contribution of SHT should be exclusively mentioned when speaking about public sector organizations. In this case, the term "stakeholders" covers the whole society or especially large parts of it. Stakeholder engagement in solving issues of societal well-being can therefore manifest through direct participation in activities of non-governmental organizations, government bodies etc. (e. g. decision making) or indirect participation incorporating significant actors into stakeholder networks.

Network theory. Representatives of political science and sociology employ the metaphor of network for explanation of political decision-making processes [32]. Network is a dynamic structure involving entities in different volumes and intensities. Networked organizations create a system of dependent variables without having a permanent organizational structure [2].

Concept of network theory was based by Kickert et al. [23], while Agranof and McGuire [3] processed the acquired empirical data and suggested a model of public network management. The network theory states that the performance of an organization is not based on hierarchical structures only, but on interaction between the components of the network. Therefore, network theory emphasizes the importance of facilitation, which is much more important in public sector. Facilitators must foster the members of the network, organize joint meetings and act as mediators in disputes; also, they must avoid supporting suggestions of particular interest groups and making one-man decisions [23]. The success of network structures is largely determined by the executives of organizations who should assume the function of a network conductor which is to create, manage and employ vertical as well as horizontal linkages among stakeholders [3].

The difference between Network theory and SHT and TCE is that it discusses subject relations, their directions and characteristics of the whole network rather than the interaction between actors and their influence on one another. 
The principle assumptions of all three theories are widely reflected in participatory and collaborative governance concepts which are important to consider to reasonably examine the issue of stakeholder participation in policy making processes.

Concepts of participatory and collaborative governance. Collaborative governance is defined as a structure and process of public policy decision making that involves various stakeholders to carry out a public purpose. Meanwhile, participatory governance is considered as involvement of public, private profit and NGO actors who are not normally concerned with decision making [9;29]. While participatory government is more focused on questions on government counseling with stakeholders, collaborative governance emphasizes the process of working together in particular. Both conceptions speak about participation and collaboration in making policy decisions and assessment of social impact. However, both of them have attributes characteristic only to one or another. According to Huxham, „collaboration carries ideological connotations associated with participation and empowerment. [...] Participation generally means engagement of stakeholders in the decision-making processes that affect them.“ [20, p. 340].

Concepts of collaborative and participatory governance deals with stakeholder inclusion into decision making processes as a way to increase the social and economic efficiency of the formed policy [4].

In order to implement collaborative governance conception in practice, it should be accepted that public interest and overcoming society's problems is of highest importance. In reality, it is complicated because interest groups compete with one another on a political level. It is hard for interest groups to give up on adversarialism and corporatism just like it is hard for the government to give up on managerialism [13].

Successful collaboration between stakeholders and the government depends on engagement of key stakeholders because weak engagement of stakeholders undermines the legitimacy of collaborative outcomes. Based on scientific research, authors state that exclusion of stakeholders can lead to situation where alternative forum will be formed [4]. Thus, it makes sense that the results of collaboration become distorted while the decisions that solve social and economic problems and due to which intersectoral collaboration takes place are usually inefficient.

Therefore, it is extremely important to find a way to ensure a balanced stakeholder participation in policy making in every case.

General provisions of inter-organizational interaction. The main value of partnership and inter-organizational collaboration is the effect of manifold synergy between actors, the goal they seek and processes they perform. Partnership is intended to implement social, economic and political programs and to solve problems common to stakeholders while collaboration is mainly characterized by the time given for joint work, especially to reach high level of trust and joint resources, from material to intellectual [31].

In social partnership, joint activity of organizations functioning in different sectors is of the highest value [34]; the competitive advantage is gained when neither partner can be changed or eliminated due to its unique position [33]. Partners that share common interests and joint goal rise to the next level of integration, the so called inter-organizational collaboration. As collaboration is a voluntary commitment in its nature, joint action requires stakeholders' commitment to behave on a non-competitive basis [17]. As a result, the live involvement of actors from organizations participating in joint activities, equal status in decision-making, efficiency of internal communication and continuous and 


\section{Economics and Management -}

reciprocal informative relations with a target group are of highest importance in collaboration $[38 ; 16]$.

The more intensively the organizations are involved into joint activities, the closer relations between them are formed and the higher joint results can be expected [36]. The process of implementation of partnerships and collaboration is full of difficulties. Many partnerships collapse due to bad understanding, incorrect allocation of costs and benefits, and distrust [1]. Thus, the principle assumptions of partnership and collaboration formed by scientists and verified by practitioners should be referred to by stakeholders with joint or overlapping goals.

\section{Methodological substantiation of the research construct}

The qualitative research methodological construct is based on analysis of beforementioned theories. It allows to identify the characteristics of associated agricultural producers' participation in agriculture policy making processes through economic benefit, engagement and commitment, influential power, nature of reciprocal relations and potential and constraints of collaboration (Figure 4.)

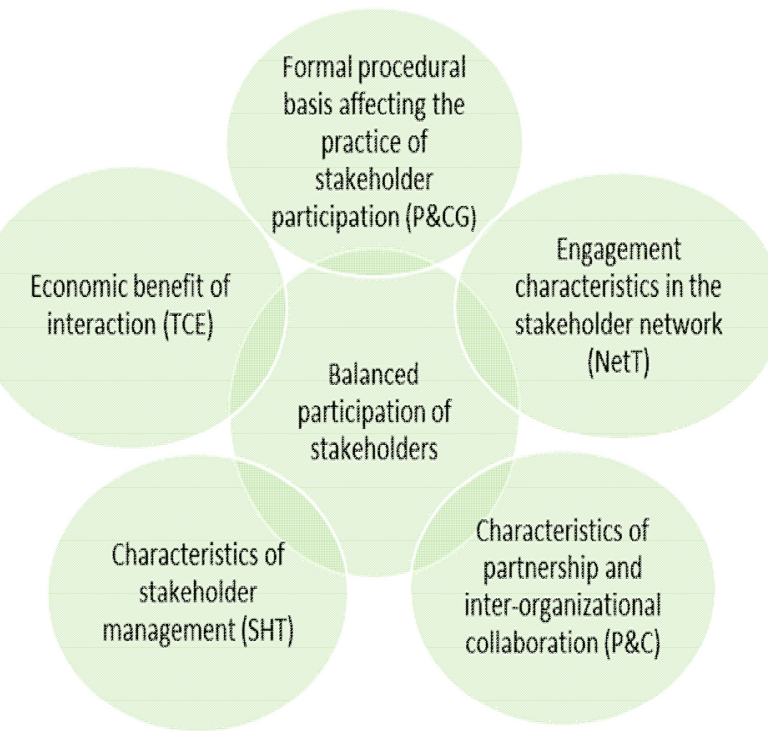

Figure 4. Groups of characteristics of associated agricultural producer organizations'
participation in agricultural policy making processes. Source: authors.

The distinguished characteristics of associated agricultural producer groups form a basis to study the specifics of such producers' participation in agricultural policy making and to prepare detailed instrumentation for research on the balance of the satisfaction of their needs and expression of interests. The instrumentation is schematically depicted in Figure 5.

The hypotheses of the research could be verified by a quantitative research. However, it is not the goal of this article and the instrumentation for quantitative research is not discussed further in the article. 


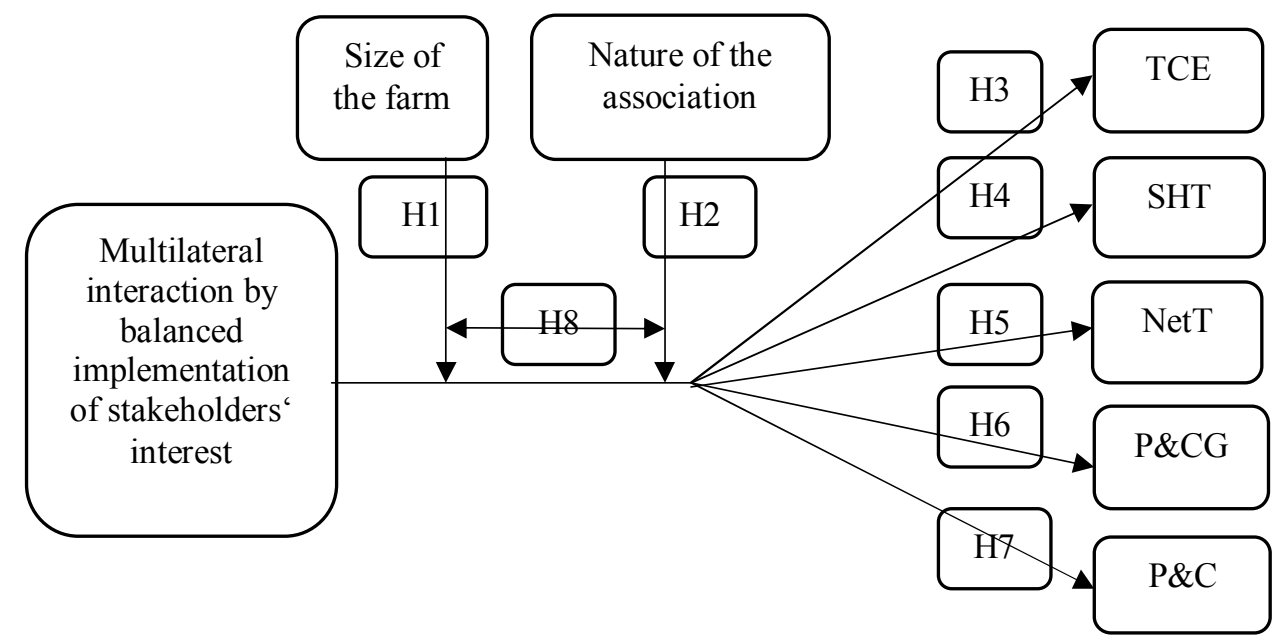

Figure 5. The scheme of research on the balance of associated agricultural producers' need satisfaction and interest expression.

Source: authors.

In order to determine what opportunities associated agricultural producer organizations have to express the needs and interests of their represented members, an expert, semistructured interview of farmer association leaders would be valuable. The interview would be carried out in a homogenous sample because all agricultural producer organizations in Lithuania and the EU have equal legal opportunities to participate in the policy making and implementation processes while the leaders of associations can take on the initiative in intersectoral activities in order to better meet the farmers' needs.

The interview questions were shaped on theoretical approaches discussed in the section above. Theory-based battery of research questions are shown at a Table 2.

Table 2

A construct of an interview: theory-based battery of research questions

Q1 - Transaction Costs Economics theory (TCE):

What economic benefit the associations achieve both separately and together and what benefit could they expect from participating in policy making processes?

$$
\text { Q2 - Stakeholder Theory (SHT): }
$$

How are the farmers' needs and expectations, and association's interests taken into account when forming agricultural policy at the State level?

Q3 - Network Theory:

How organized and enabling is the structure of associated agricultural producer network?

Q4 - Concepts of Participative and Collaborative Governance (P\&CG):

What structures and processes ensure the engagement of stakeholders of different sector, activity, volume and skills in the agricultural policy making processes?

$$
\text { Q5 - Partnership and inter-organizational collaboration (P\&C): }
$$

How satisfied are the agricultural producers with their reciprocal partnership and interorganizational and interinstitutional collaboration results and process?

Source: authors. 
The interview is designed to collect qualitative data required to better understand the problem context of agricultural producers' expression of interest.

The questions of Q1 group are meant to receive information about how the representatives of associated agricultural producers evaluate the opportunity to express the economic needs and interests of members they represent; if they have a possibility to initialize decisions based on needs and interests and propose decision corrections; if they collaborate with other associated agrarian organizations etc.

The questions of Q2 group help to find out if the needs expressed by agricultural producers and their associated organizations are held equally important in making agricultural policy decisions; how dominant interests are balanced out; how less active associated organizations of agricultural producers are included etc.

Q3 group's questions are meant to determine the existing relation structure by the power to influence agricultural policy decisions on a state level; how interorganizational and interinstitutional meetings between associated agricultural producer organizations are organized; what the essential characteristics of interorganizational relations in the agricultural producer representatives network are etc.

Q4 group's questions help to ascertain the principles of stakeholder engagement the governmental institutions follow and to determine if this procedure allows to ensure a balanced expression of interests as well as to find out what problems are solved by joint work between groups or institutions etc.

Questions of Q5 group are designed to receive information on the level of trust between agricultural producer organizations; what synergy stakeholder cooperation creates; what prevents joining intellectual, material and other resources to achieve both agricultural policy decisions that satisfy needs and interests and efficiency and effectiveness of activity etc.

Semi-structure interview provides the researcher with the opportunity to shift the conversation to relevant questions, ask additional questions or clarifications. Therefore, this interview should not be taken as an instruction but rather guidelines that facilitate the researchers' work and allow to maintain the theoretical methodological integrity of the research.

\section{Conclusions}

The analysis of scientific literature allows to state that a scientific and practical problem of stakeholder participation in policy making processes exists. In the context of the common agricultural policy of the EU and particularly in the context of EU financial support for agriculture, this problem is faced by a wide circle of stakeholders and becomes especially sore because it deforms the opportunities of big and small farmers to defend their interests.

In order to solve this problem, the article forms a theoretically and methodologically substantiated construct of associated agricultural stakeholder organizations ' influential power and participation in agricultural policy making. Based on the Transaction Costs Economics theory, Stakeholder Theory, Network Theory as well as the concept of Participative and Collaborative Governance and concept of partnership and interorganizational collaboration, the following were achieved:

a. Characteristic groups of associated agricultural producer organizations ‘ participation in agricultural policy making processes were distinguished;

b. A scheme of research on the balance of need satisfaction and interest expression of associated agricultural producers was compiled; 
c. A theory-based battery of interview questions for further research of stakeholder in agriculture was formed.

Research proposed in the article could strengthen the assumptions for better opportunities to take agricultural stakeholder needs into consideration when forming and implementing agricultural policy. It should be emphasized that the implementation of interests based on needs, not wishes, principles or intent should become a core task for policy makers. In order to do so, it must be ensured that stakeholders' influential power is balanced, and the needs of all interest groups are appropriately evaluated.

Research on representation of agricultural producers' interests, conducted based on the theoretical and methodological construct of the research would allow to systematically gather qualitative data and better substantiate recommendations to politicians and representatives of agricultural producer associations who seek to more efficiently engage and participate in agricultural politics.

\section{References}

1. Afsarmanesh M., Camarinha-Matos L., Soares A.L. (Eds.) (2016), Collaboration in a Hyperconnected World. 17th IFIP WG 5.5 Working Conference on Virtual Enterprises, PRO-VE 2016, Porto, Portugal, October 3-5, 2016, Proceedings, Springer.

2. Agranoff R., McGuire M. (2001), After Network Is Formed: Process, Power and Performance, In Mandel (ed.) Getting Results through Collaboration: Networks and Network Structures for Public Policy and Management, Quorum Books.

3. Agranoff R., McGuire M. (2003), Inside the Matrix: Integrating the Paradigms of Intergovernmental and Networking Management, International Journal of Public Administration, 26(12), pp. 1401-1422.

4. Ansell Ch., Gash A. (2007), Collaborative Governance in Theory and Practice, Journal of Public Administration Research and Theory, 18, pp. 548-571.

5. Bureau, J.C., Mahé L.P. (2008), CAP Reform Beyond 2013: An Idea for a Longer View. http://www.notre-europe.eu/uploads/tx_publication/Etude64-CAP-Propositions-EN_01.pdf

6. Csaki C., Forgacs C. (2009), Small Farms in Central and Eastern Europe: Is There a Future for Them? University of Kent, Canterbury, UK.

7. European Commission (2017), Direct Payments, Single Area Payment Scheme and Transitional National Aid.

8. Donaldson T., Preston L.E. (1995), The stakeholder theory of the corporation: concepts, evidence, and implications. Academy of Management Review, 20(1), pp. 65-91.

9. Emerson K., Nabatchi T. (2015), Collaborative Governance Regimes. Washington, DC: Georgetown University Press.

10. European Commission (2011), EU Agricultural Economic Briefs. What is a small farm? Brief, 2.

11. Freeman R.E. (1999), Response: divergent stakeholder theory, Academy of Management Review, 24(2), pp. 233-236.

12. Frooman J. (1999), Stakeholder influence strategies, Academy of Management Review, 24(2), pp. 191-205.

13. Futrel R. (2003), Technical advertarialism and participatory collaboration in the U.S. chemical weapons disposal program, Science, Technology and Human Values, 28, pp. 451-482.

14. Gay S. H., Osterburg B., Baldock D., \& Zdanowicz A. (2005), Recent evolution of the EU Common Agricultural Policy (CAP): state of play and environmental potential. MEACAP WP6, D4b, Federal Agricultural Research Centre, Braunschweig and Institute for European Environmental Policy, London.

15. Ghoshal S., Moran P. (1996), Bad for Practice: A Critique of the Transaction Cost Theory, The Academy of Management Review, 21(1), pp. 13-47.

16. Gray B. (1985), Conditions facilitating interorganisational collaboration. Human Relations, 39(10), pp. 911-936. 
17. Henneman E.A., Lee J.L., Cohen J.I. (1995), Collaboration: concept analysis. Journal of Advanced Nursing, 21, pp. 103-109.

18. Hill C.W.L. (1990), Cooperation, Opportunism, and the Invisible Hand: Implications for Transaction Cost Theory, The Academy of Management Review, 15(3), pp. 500-513.

19. Hubbard C. (2009), Small farms in the EU: How Small is Small? University of Kent, Canterbury, UK.

20. Huxham C.H. (2000), The challenge of collaborative governance, Public Management, 2(3), pp. $337-357$.

21. Jones T.M., Wicks A.C. (1999), Convergent stakeholder theory, Academy of management review, 24(2), pp. 206-221.

22. Katsarova I. (2013), Common Agricultural Policy after 2013. What will change, Library of the European Parliament-Library Briefing.

23. Kickert W.J., Klijn E.H., Koppenjan J. (1997), Managing Complex Networks: Strategies for the Public Sector, Sage Publications, London.

24. Le Ber, M.J., Branzei, O. (2010), (Re)Forming Strategic Cross-Sector Partnerships: Relational Processes of Social Innovation, Business \& Society, 49(1), pp. 140-172.

25. Melnikienè R., Volkov A. (2013), Impact of the CAP support measures on the agricultural sector in Lithuania, Economic, social and institutional factors in the growth of agri-food sector in Europe, Multi-Annual programme 2011-2014, 67(1), pp. 112-127.

26. Milašius A. (2018), Ükininkai suskilo - kuria alternatyva Žemés ūkio rūmams. Accessed (23-072018) on https://www.delfi.lt/agro/agroverslo-naujienos/ukininkai-suskilo-kuria-alternatyvazemes-ukio-rumams.d?id=77797353

27. Milgrom P.R., Roberts I. (1992), Economics, orgranization and management. Englewood Cliffs, NJ: Prentice Hall.

28. Mitchell R.K., Agle B.R. \& Wood D.J. (1997), Toward a theory of stakeholder identification and salience: defining the principle of who and what really counts, Academy of Management Review, 22(4), pp. 853-886.

29. Newig J., Challies E., Jager N.W., Kochskaemper E., Adzersen A. (2017), The Environmental Performance of Participatory and Collaborative Governance: A Framework of Causal Mechanisms, Policy Studies Journal, pp. 1-29.

30. Post J.E., Preston L.E., Sachs S. (2002), Managing the extended enterprise: the new stakeholder view, California management review, 45(1), pp. 6-28.

31. Raisiene A.G. (2009), In Quest of Integrated Collaboration, LAP LAMBERT Academic Publishing AG \& Co. KG, Saarbrucken.

32. Rethemeyer K.R. (2005), Conceptualising and Measuring Collaborative Networks, Public Administration Review, 65 (1), pp. 117-121.

33. Samii R., Van Wassenhove L.N., Bhattacharya S. (2002), An Innovative Public-Private Partnership: New Approach to Development, World Development, 30 (6), pp. 991-1008.

34. Seitanidi M.M., Koufopoulos D.N., Palmer P. (2010), Partnership Formation for Change: Indicators for Transformative Potential in Cross Sector Social Partnerships, Journal of Business Ethics, 94, pp. 139-161.

35. Swinnen, J. (Ed.) (2010), The Political Economy of the Most Radical Reform of the Common Agricultural Policy, Centre for European Policy Studies.

36. Torres G.W., Margolin F.S. (2003), The Collaboration Primer. Proven Strategies, Considerations and Tools to Get Your Started, HRET, pp. 20.

37. Vidickienė D.; Melnikienè R. (2014), Kaimo politikos evoliucija, Lietuvos agrarinès ekonomikos institutas, pp. 272.

38. Vigoda-Gadot E. (2004), The case for collaboration: A road map based on the Carmelite project in Israel and some lessons for revitalizing democracies, Public Administration and Management Journal, 9(1), pp. 1-14.

39. Williamson O.E. (1991a), Strategizing, economizing, and economic organization, Strategic Management Journal, 12, pp. 75-94.

40. Zahrnt V. (2009a), Public money for public goods: winners and losers from CAP reform, European Centre for International Political Economy, pp. 1-37.

41. Zahrnt V. (2009b), The Budgetary Aspects of The New CAP Payments: note, Policy Department B: Structural and Cohesion Policies. 